\title{
Groundwater availability in the United States: the value of quantitative regional assessments
}

\author{
Kevin F. Dennehy ${ }^{1} \cdot$ Thomas E. Reilly $^{1} \cdot$ William L. Cunningham ${ }^{1}$ \\ Received: 22 May 2015 / Accepted: 5 August 2015 /Published online: 18 September 2015 \\ (C) The Author(s) 2015. This article is published with open access at Springerlink.com
}

Keywords Groundwater management · Groundwater availability $\cdot$ Regional assessments $\cdot$ Quantitative analysis · USA

\section{Introduction}

The sustainability of water resources is under continued threat from the challenges associated with a growing population, competing demands, and a changing climate. Freshwater scarcity has become a fact in many areas. Much of the United States surface-water supplies are fully apportioned for use; thus, in some areas the only potential alternative freshwater source that can provide needed quantities is groundwater. Although frequently overlooked, groundwater serves as the principal reserve of freshwater in the US and represents much of the potential supply during periods of drought.

Some nations have requirements to monitor and characterize the availability of groundwater such as the European Union's Water Framework Directive (EPCEU 2000). In the US there is no such national requirement. Quantitative regional groundwater availability assessments, however, are essential to document the status and trends of groundwater availability for the US and make informed water-resource decisions possible now and in the future.

Barthel (2014) highlighted that the value of regional groundwater assessments goes well beyond just quantifying the resource so that it can be better managed. The tools and techniques required to evaluate these unique regional systems advance the science of hydrogeology and provide enhanced methods that can benefit local-scale groundwater investigations. In addition, a significant, yet under-utilized benefit is the digital spatial and temporal data sets routinely generated as part of these studies.

Kevin F. Dennehy

kdennehy@usgs.gov

1 US Geological Survey, Reston, VA, USA
Even though there is no legal or regulatory requirement for regional groundwater assessments in the US, there is a logical basis for their implementation.

The purpose of this essay is to articulate the rationale for and reaffirm the value of regional groundwater assessments primarily in the US; however, the arguments hold for all nations. The importance of the data sets and the methods and model development that occur as part of these assessments is stressed. These high-value data sets and models should be available in readily accessible formats for use today and in the future. Examples of advances in and accomplishments of two regional groundwater assessments are presented to demonstrate their function, relevance, and value for determining the sustainability of the groundwater resources of the US.

\section{Groundwater availability: an issue of scale}

Identifying sustainable water supplies to meet the water demands of the US is a worthwhile goal. However, what is the appropriate scale of investigation? In the US, water decisions generally are made at the local level and typically are not based on a comprehensive holistic analysis of the entire aquifer system supplying the water resource. It is understood that local groundwater availability is a function of regional processes as well as local processes. However, water agencies at various levels of government necessarily focus on the local groundwater resources within their jurisdiction. Yet changes in the aquifer that occur beyond local and state political boundaries can affect groundwater availability at the local scale. Therefore, there is a genuine need for a systematic and comprehensive strategy to provide technical information and tools over larger areas that will provide context for the difficult decisions of what water is available at local scales, today and in the future.

At present, information pertaining to the US's groundwater resources is not available in consistent spatial and temporal scales across the country. The large US land area and the three-dimensional (3D) nature of the geology and groundwater systems makes that difficult. Additionally, the response times of regional groundwater systems are long and the consequences 
of pumping may not be understood until after it happens and, once detected, the consequences may be irreversible (e.g. Bredehoeft and Durbin 2009). There is a pragmatic need to quantify groundwater availability through a deterministic systems analysis approach that relates cause and effect at the spatial and temporal scale of the hydrologic drivers. Within the US and elsewhere, most water management plans are surface water (watershed) centric. For understanding groundwater, a regional groundwater system delineated by clearly defined hydrogeologic boundaries is a useful scale upon which to base this quantitative systems analysis. The areal and vertical location of regional aquifers is fundamental to the determination of groundwater availability.

The principal aquifers of the US are identified and described in the "Ground Water Atlas of the United States" (Miller 2000) and shown on a two-dimensional (2D) map representation (Fig. 1; USGS 2003). The identification of these principal aquifers affords a broad understanding of where water-bearing formations are in the US and provides a framework to classify and study regional groundwater systems. These naturally bounded regional aquifer systems can then be assessed using actual physical hydrologic boundaries, which minimizes many of the assumptions required to analyze groundwater in unbounded local areas. Results from these regional assessments can be scaled up to a national synthesis and scaled down to provide information relevant to issues of local concern.

A quantitative regional assessment is the analysis of a bounded regional groundwater system using numerical models to estimate and better understand the components of the hydrologic system. These components form a water budget that can be used to aid management of the resource. A numerical model provides a workable platform to incorporate the appropriate level of aquifer complexity. Their use serves two purposes: the relevant hydrologic processes are represented in a holistic manner, and the stress and response of the system are represented mathematically, which enables forecasting the response of future changes in the hydrologic system. The complexity and sophistication of the model will depend on the current level of understanding of the groundwater system and the key issue to be addressed. Thus, numerical simulations may range from simple exploratory models to complex models representing fully coupled hydrological processes.

\section{Value of quantitative regional groundwater assessments}

In the US and elsewhere, there is clear evidence of areas undergoing depletion of this natural resource (Konikow 2013). Some depletion is expected with any use of the resource; however, substantial continuing depletion may be an indicator of unsustainable use of the resource. Regional quantitative assessments are requisite to understand the magnitude and the relative seriousness of any depletion beyond the local scale.

Global stresses such as climate variability (particularly drought) and change suggest that the entire regional groundwater system be analyzed, quantified, and understood because the stress cannot be isolated to specific subsystems or political jurisdictions. The response of the entire system will dictate how local organizations should respond to estimated changes in the water-resources system or its effect on other parts of the system. Thus, understanding the sources of water and internal flow systems of regional aquifers is important to the development of an effective resource management policy.

In the US, there is much information available at the regional and national scales on different components of the hydrologic system. For example, a recent major advancement is the use of the GRACE (the Gravity Recovery and Climate Experiment) satellite system (Famiglietti and Rodell 2013) to estimate changes in groundwater storage from changes in gravity over time. Maps of other key hydrologic budget components such as
Fig. 1 Principal aquifers of the United States (for simplicity the sand and gravel aquifers located in glacial deposits distributed across the northern continental US are not shown) (USGS 2003). Visit USGS (2015b) for more information on regional groundwater availability studies

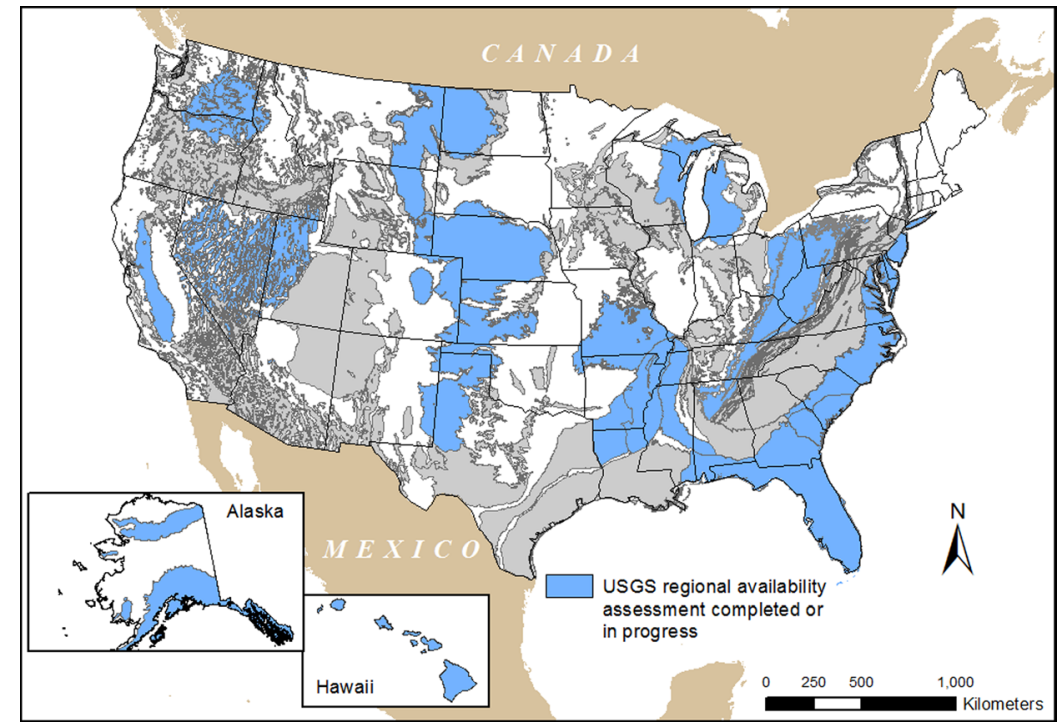


groundwater recharge (Wolock 2003) and evapotranspiration for the conterminous US (Sanford and Selnick 2013), are useful in putting the national groundwater system in perspective. These continental-scale products do not, however, address all the spatial and temporal variability of the water-budget components for a specific aquifer that need to be quantified for management of the resource, nor can they forecast future conditions. Regional numerical models are effective means to provide that quantitative analysis and create the link between the local and national scale.

Numerous sub-regional and regional groundwater investigations have been conducted in the US by various local, state, and federal entities (e.g. Rossman and Zlotnik 2013 and Sun and Johnston 1994). On a national scale, the US has a broad knowledge of the country's groundwater resources (Reilly et al. 2008); however, this knowledge can be improved with the application of new technologies and use of the latest information as groundwater systems change.

In principal aquifers where assessments have been previously conducted using numerical models, future assessments can either update the available model with current water use or revise the basic model design to take advantage of new information and new modeling techniques. In principal, aquifers that have not previously been modeled, the development of a modeling tool will serve the current assessment as well as form the foundation for future assessments as data (on hydrogeology, water use, land use, climate, etc.) and improved modeling techniques become available.

Quantitative regional groundwater systems analyses should estimate current conditions and trends in groundwater use, storage, recharge, and discharge making it possible to develop groundwater budgets leading to a greater understanding of the complete aquifer system. Once the effect of groundwater use and development are quantified, water managers can make informed decisions on the best use of the resource. For example, there are two recent assessments in the US that demonstrate the benefits of quantitative understanding of regional groundwater systems:

1. The US Bureau of Reclamation along with the California Department of Water Resources and a number of water districts use the Central Valley Hydrologic Model (CVHM) tool (Faunt 2009) and information developed as part of the regional groundwater assessments to better understand how water moves through the aquifer system, predict watersupply scenarios, analyze subsidence, and address issues related to the conjunctive use of water in California. The CVHM is being updated with relevant information to assess and forecast how the current (2013-2015) California drought on top of the recent drought (2006-2009) will affect hydrologic conditions and subsidence in the Central Valley.

2. An increased understanding of the Mississippi Embayment Regional Aquifer System (MERAS) through the use of a numerical model (Clark and Hart 2009) helped document the effects of human activities and climate variability on groundwater levels, depletion, storage, and interaction with surface water. This helped water managers to develop the Arkansas State Water Plan (Arkansas Natural Resources Commission 2014).

Other benefits from the development of regional modeling tools include the refinement of spatial and temporal estimates of geologic, hydrologic, climatic, and human-influenced variables within the principal aquifer systems. For example, digital spatial and temporal data produced from the characterization of principal and major aquifer systems by the US Geological Survey (USGS) are provided online as open data in easily accessible formats (USGS 2015a). Regional models also should be routinely preserved and archived for use by interested parties. As an example, all regional numerical models developed by USGS are published, archived, and freely available upon request. All scientists should be encouraged to take the same approach given the advent of open data policies in many scientific journals.

Recent USGS regional groundwater-availability-assessment activities (Fig. 1) have led to improvements and innovations in process-oriented groundwater science as called for by Barthel (2014). Application, testing, and development of modeling tools and techniques such as the local grid refinement (Mehl and Hill 2007) and the unstructured grid approach for MODFLOW (Panday et al. 2013) are examples of advancements that stem from a need to examine the resource at a variety of scales. Techniques to estimate spatial and temporal variability in recharge (Westenbroek et al. 2010), determination of actual evapotranspiration using remotely sensed data (Stanton et al. 2011), and the development of the Farm Process (Schmid et al. 2006) used to simulate conjunctive use of surface water and groundwater for irrigated agriculture, are also results that have evolved from regional groundwater availability assessments. These advancements are transferable and improve hydrologic science that can be used to analyze groundwater systems at any scale.

\section{Summary and perspective}

Around the world (WWAP 2015, p. 12) and as indicated by the European Union Water Framework Directive, there is a need to quantify the world's groundwater resource and improve the methods available for its assessment. This is especially important at this time for the US, given the documented occurrence of groundwater depletion and climate variability (drought) and change. Although some regional aquifers are well characterized, much remains to be accomplished in the assessment of the groundwater resources of the US.

Analyzing entire groundwater systems that are delineated by physical hydrologic boundaries and are continuous across political boundaries has practical advantages in that a regional analysis removes many of the assumptions and constraints that can affect local analysis. Local water managers are necessarily 
focusing at different spatial and temporal scales than what is required to address aquifer sustainability. Regional analyses, however, can address aquifer sustainability by taking into account known hydrologic boundaries, observed data, and multiple stresses in a straightforward, holistic manner. Furthermore, regional assessments can advance the state-of-knowledge of large groundwater systems, aid in their management, and incrementally improve the science of hydrology. Numerical modeling is particularly helpful in hypothesis testing over large spatial and temporal scales to aid in the identification of the driving parameters and processes that control groundwater system response.

Local governments and related water agencies are responsible for management of their resources, but that management should be done with an awareness of the regional system. Higher levels of government should take a regional perspective and by some means (guidelines, regulations, funding, research) encourage local water agencies to make decisions within that broader context. Our role as hydrogeologists is to facilitate this awareness by advancing the understanding of the regional groundwater system, quantifying the response of the groundwater system using the latest tools available, advancing the methods of study, and advocating for science-based water management.

As the water availability in regional systems is evaluated and quantified, the conceptual understanding and the results of the numerical models should be made available to all interested parties so future work can more easily build upon previous work. This can be accomplished through publication of study results and free access to archived model input and supporting data sets and the numerical models themselves, whether by the federal government, academia, or other non-governmental organizations. Given this potential of free exchange of aquifer information, it should be possible to begin to synthesize the responses observed in similar systems to aid in extrapolation to other related systems in areas not previously studied. Ideally, it would be cost effective and most efficient to maintain these regional numerical modeling tools to reassess groundwater availability as water use, land use, climatic conditions, and societal perspectives change through time.

Open Access This article is distributed under the terms of the Creative Commons Attribution 4.0 International License (http:// creativecommons.org/licenses/by/4.0/), which permits unrestricted use, distribution, and reproduction in any medium, provided you give appropriate credit to the original author(s) and the source, provide a link to the Creative Commons license, and indicate if changes were made.

\section{References}

Arkansas Natural Resources Commission (2014) Arkansas State water plan update: water availability report. Arkansas Natural Resources Commission. http://www.arwaterplan.arkansas.gov/reports.html. Accessed July 23, 2015

Barthel R (2014) A call for more fundamental science in regional hydrogeology. Hydrogeol J. doi:10.1007/s10040-014-1101-9

Bredehoeft J, Durbin T (2009) Ground water development: the time to full capture problem. Ground Water 47(4):506-514
Clark BR, Hart RM (2009) The Mississippi Embayment Regional Aquifer Study (MERAS): documentation of a groundwater-flow model constructed to assess water availability in the Mississippi Embayment. US Geol Surv Sci Invest Rep 2009-5172, 61 pp

EPCEU (The European Parliament and the Council of the European Union) (2000) Directive of 23 October 2000 establishing a framework for community action in the field of water policy, Directive 2000/60/EC. Off J Eur Comm L 327, 72 pp

Famiglietti JS, Rodell M (2013) Water in the balance. Science 340:1300-1301

Faunt CC (ed) (2009) Groundwater availability of the Central Valley Aquifer, California. US Geol Surv Prof Pap 1766, 225 pp

Konikow LF (2013) Groundwater depletion in the United States (19002008). USGeol Surv Sci Invest Rep 2013-5079, 63 pp

Mehl SW, Hill MC (2007) The US Geological Survey modular groundwater model: documentation of the multiple-refined-areas capability of local grid refinement (LGR) and the boundary flow and head (BFH) package, US Geol Surv Techniques and Methods, book 6, chap A21, USGS, Reston, VA, 13 pp

Miller JA (ed) (2000) Ground water atlas of the United States, U.S. Geological Survey Hydrologic Atlas 730, chapters A-N published separately, USGS, Reston, VA

Panday S, Langevin CD, Niswonger RG, Ibaraki M, Hughes JD (2013) MODFLOW-USG version 1: an unstructured grid version of MODFLOW for simulating groundwater flow and tightly coupled processes using a control volume finite-difference formulation. US Geol Surv Techniques and Methods, book 6, chap A45, USGS, Reston, VA, $66 \mathrm{pp}$

Reilly TE, Dennehy KF, Alley WM, Cunningham WL (2008) Ground-water availability in the United States. US Geol Surv Circ 1323, 70 pp

Rossman NR, Zlotnik VA (2013) Review: Regional groundwater flow modeling in heavily irrigated basins of selected states in the western United States. Hydrogeol J 21:1173-1192

Sanford WE, Selnick DL (2013) Estimation of evapotranspiration across the conterminous United States using a regression with climate and land-cover data. J Am Water Resour Assoc 49(1):217-230

Schmid W, Hanson RT, Maddock T III, Leake SA (2006) User guide for the farm process (FMP1) for the U.S. Geological Survey's modular three-dimensional finite-difference ground-water flow model, MODFLOW-2000. US Geological Survey Techniques and Methods, book 6, chap A17, USGS, Reston, VA, 127 pp

Stanton JS, Qi SL, Ryter DW, Falk SE, Houston NA, Peterson SM, Westenbroek SM, Christenson SC (2011) Selected approaches to estimate water-budget components of the High Plains, 1940 through 1949 and 2000 through 2009. US Geol Surv Sci Invest Rep 2011-5183, 79 pp

Sun RJ, Johnston RH (1994) Regional aquifer-system analysis program of the US Geological Survey, 1978-1992. US Geol Surv Circ 1099, 126 pp

USGS (2003) Principal aquifers of the 48 conterminous United States, Hawaii, Puerto Rico, and the US Virgin Islands, U.S. Geological Survey National Atlas of the United States. USGS, Reston, VA

USGS (2015a) Data \& information: geospatial data. US Geological Survey. http://water.usgs.gov/ogw/gwrp/activities/fundamental_ data.html. Accessed July 23, 2015

USGS (2015b) Regional groundwater availability studies. US Geological Survey. http://water.usgs.gov/ogw/gwrp/activities/gw-avail.html. Accessed July 23, 2015

Westenbroek SM, Kelson VA, Dripps WR, Hunt RJ, Bradbury KR (2010) SWB: a modified Thornthwaite-Mather soil-water-balance code for estimating groundwater recharge. US Geological Survey Techniques and Methods, book 6, chap A31, USGS, Reston, VA, 60 pp

Wolock DM (2003) Estimated mean annual natural ground-water recharge in the conterminous United States, US Geol Surv OpenFile Rep 03-311, digital dataset. http://water.usgs.gov/lookup/ getspatial?rech48grd. Accessed July 23, 2015

WWAP (United Nations World Water Assessment Programme) (2015) The United Nations World Water Development Report 2015: water for a sustainable world. UNESCO, Paris, 122 pp 